\title{
Enhanced Nociception in Angelman Syndrome Model Mice
}

\author{
Eric S. McCoy, ${ }^{1 \star}$ Bonnie Taylor-Blake, ${ }^{1 \star}$ Megumi Aita, ${ }^{1}$ - Jeremy M. Simon, ${ }^{1,2,3}$ Benjamin D. Philpot, ${ }^{1,2}$ \\ and Mark J. Zylka ${ }^{1,2}$ \\ ${ }^{1}$ Department of Cell Biology and Physiology and University of North Carolina Neuroscience Center, ${ }^{2}$ Carolina Institute for Developmental Disabilities, \\ and ${ }^{3}$ Department of Genetics, University of North Carolina, Chapel Hill, North Carolina 27599
}

Angelman syndrome (AS) is a severe neurodevelopmental disorder caused by mutation or deletion of the maternal $U B E 3 A$ allele. The maternal $U B E 3 A$ allele is expressed in nearly all neurons of the brain and spinal cord, whereas the paternal $U B E 3 A$ allele is repressed by an extremely long antisense transcript (UBE3A-ATS). Little is known about expression of $U B E 3 A$ in the peripheral nervous system, where loss of maternal UBE3A might contribute to AS phenotypes. Here we sought to examine maternal and paternal Ube3a expression in DRGs neurons and to evaluate whether nociceptive responses were affected in AS model mice (global deletion of maternal Ube3a allele; Ube $\left.3 a^{m-1 p^{+}}\right)$. We found that most large-diameter proprioceptive and mechanosensitive DRG neurons expressed maternal Ube3a and paternal Ube3a-ATS. In contrast, most small-diameter neurons expressed Ube3a biallelically and had low to undetectable levels of Ube3a-ATS. Analysis of single-cell DRG transcriptomes further suggested that Ube3a is expressed monoallelically in myelinated largediameter neurons and biallelically in unmyelinated small-diameter neurons. Behavioral responses to some noxious thermal and mechanical stimuli were enhanced in male and female AS model mice; however, nociceptive responses were not altered by the conditional deletion of maternal Ube $3 a$ in the DRG. These data suggest that the enhanced nociceptive responses in AS model mice are due to loss of maternal Ube $3 a$ in the central, but not peripheral, nervous system. Our study provides new insights into sensory processing deficits associated with AS.

Key words: Angelman syndrome; nociception; Ube3a

\section{Significance Statement}

Angelman syndrome (AS) is a neurodevelopmental disorder caused by loss or mutation of the maternal UBE3A allele. While sensory processing deficits are frequently associated with AS, it is currently unknown whether Ube3a is expressed in peripheral sensory neurons or whether maternal deletion of $U b e 3 a$ affects somatosensory responses. Here, we found that $U b e 3 a$ is primarily expressed from the maternally inherited allele in myelinated large-diameter sensory neurons and biallelically expressed in unmyelinated small-diameter neurons. Nociceptive responses to select noxious thermal and mechanical stimuli were enhanced following global, but not sensory neuron-specific, deletion of maternal Ube $3 a$ in mice. These data suggest that maternal loss of Ube $3 a$ affects nociception via a central, but not peripheral mechanism, with implications for AS.

\section{Introduction}

Angelman syndrome (AS) is caused by mutation or deletion of the maternally inherited UBE3A allele (located in the chr15q11.2-

\footnotetext{
Received April 14, 2017; revised Sept. 7, 2017; accepted Sept. 11, 2017.

Author contributions: E.S.M., B.T.-B., and M.J.Z. designed research; E.S.M., B.T.-B., and M.A. performed research; B.D.P. contributed unpublished reagents/analytic tools; E.S.M., B.T.-B., M.A., and J.M.S. analyzed data; E.S.M., B.T.-B., J.M.S., and M.J.Z. wrote the paper.

This work was supported by Angelman Syndrome Foundation to M.J.Z. and B.D.P., and National Institutes of Health Grants R01NS081127 and DP1ES024088 to M.J.Z., and Grant R01NS085093 to B.D.P. Imaging work was performed at the Microscopy Imaging Core at the University of North Carolina Neuroscience Center. The Bioinformatics Core (J.M.S.) and the Confocal Microscopy Core were supported by National Institute of Neurological Disorders and Stroke Grant P30NS045892 and National Institute of Child Health and Human Development Grant U54HD079124. We thank Ji Han and Ellen Clark for managing the Ube3a-YFP mouse colony; Mike Sidorov, Alex Kloth, and Kelly Jones for managing the Ube $3 a^{m-/ p+}$ and Ube $3 a^{m+/ p+}$ mouse colony; and Matt Judson for providing the Ube $3 a^{F L O X / p+}$ mice.

The authors declare no competing financial interests.

*E.S.M. and B.T.-B. contributed equally to this work.
}

q13.3 region) (Kishino et al., 1997; Matsuura et al., 1997; Sutcliffe et al., 1997; Williams et al., 2006). UBE3A encodes an E3 ubiquitin ligase that localizes to presynaptic and postsynaptic neuronal compartments, the cytoplasm, and the nucleus (Dindot et al., 2008; Greer et al., 2010; Judson et al., 2014). UBE3A is expressed biallelically in most tissues. However, in the CNS, including brain and spinal cord (Rougeulle et al., 1997; Huang et al., 2011; LaSalle et al., 2015), full-length UBE3A protein is expressed primarily from the maternal allele because paternal $U B E 3 A$ is repressed in cis by a very long noncoding transcript known as UBE3A-ATS

Correspondence should be addressed to Dr. Mark J. Zylka, Department of Cell Biology and Physiology and UNC Neuroscience Center, University of North Carolina, Chapel Hill, NC 27599. E-mail: zylka@med.unc.edu. DOI:10.1523/JNEUROSCI.1018-17.2017

Copyright $\odot 2017$ the authors $\quad 0270-6474 / 17 / 3710230-10 \$ 15.00 / 0$ 
(Rougeulle et al., 1998; Yamasaki et al., 2003; Landers et al., 2004; Numata et al., 2011).

Many of the symptoms associated with AS can be modeled in mice with maternal deletion of Ube3a (Ube3a $a^{m-/ p+}$; AS model mice), including ataxia, epilepsy, memory impairments, and sleep disturbances (Jiang et al., 1998; Dindot et al., 2008; Mabb et al., 2011; Wallace et al., 2012; Huang et al., 2013; Ehlen et al., 2015; LaSalle et al., 2015). Based on parent reports and questionnaires, sensory processing deficits are also frequently associated with AS, including seemingly slow responses to pain in at least half of all individuals (Artigas-Pallarés et al., 2005; Walz and Baranek, 2006; Pelc et al., 2008). However, whether maternal loss of UBE3A causes primary sensory deficits is unknown. It remains possible that parent-based observations are biased, particularly given that AS individuals have intellectual disabilities and do not speak, which make it difficult to accurately assess emotions (Adams and Oliver, 2011). The maternal GABRB3 allele, which encodes the $\beta 3$ subunit of the $\mathrm{GABA}_{\mathrm{A}}$ receptor, is located next to UBE3A in the genome, and is frequently deleted in $>80 \%$ of individuals with AS (Sinnett et al., 1993; Saitoh et al., 1994; Jiang et al., 2010; Buiting et al., 2016). It is thus possible that some AS-associated symptoms are due to haploinsufficiency of other genes in the UBE3A chromosomal deletion region. Heterozygous deletion of Gabrb3 in mice leads to enhanced responsiveness to thermal and mechanical stimuli (DeLorey et al., 2011; Orefice et al., 2016), although enhanced nociception was only observed in homozygous Gabrb3 mutant mice by a different group (Ugarte et al., 2000).

Somatosensory stimuli, including touch and pain, are detected by neurons in the DRGs, which reside in the peripheral nervous system. Currently, it is unknown whether Ube3a is expressed monoallelically or biallelically in DRG neurons and whether deletion of the maternal Ube3a allele affects nociceptive responses. Here, we evaluated the extent to which maternal loss of Ube3a in mice affects nociception and other somatosensory responses. Our results suggest that global loss of maternal Ube3a, but not DRG-selective loss, enhances behavioral responses to noxious thermal and mechanical stimuli. Thus, the seemingly slow responses to pain in AS individuals may relate to communication deficits and not sensory deficits.

\section{Materials and Methods}

Animal care and use. All procedures used in this study were approved by the Institutional Animal Care and Use Committee at the University of North Carolina at Chapel Hill. Mice were maintained on a $12 \mathrm{~h}: 12 \mathrm{~h}$ light/dark cycle, given food and water ad libitum, and tested during the light phase. Mice were acclimated to the testing room, equipment, and experimenter $1-3 \mathrm{~d}$ before testing.

FISH. Mice were rapidly decapitated, and vertebral columns containing spinal cord and DRGs were snap-frozen in an embedding mold of OCT compound (Fisher Scientific) over dry ice. Fresh, frozen vertebral columns were sectioned at $20 \mu \mathrm{m}$ on a cryostat (CM1950; Leica Biosystems) onto charged slides (Fisher Superfrost Plus). Fluorescein-labeled Ube3a-ATS probe was synthesized as previously described (Meng et al., 2013) and is located near the $3^{\prime}$ end of Ube3a-ATS. Tissue was dried at $50^{\circ} \mathrm{C}$ for $10 \mathrm{~min}$, fixed in $4 \%$ PFA in PBS, diethylpyrocarbonate (DEPC)treated for $15 \mathrm{~min}$, and washed in DEPC-PBS $3 \times 5 \mathrm{~min}$. The tissue was then acetylated in $1 \times$ triethanolamine- $\mathrm{HCl}$ with $0.25 \%$ acetic anhydride for $10 \mathrm{~min}$ and subsequently washed in DEPC-PBS $3 \times 5$ min each. Next, the tissue was prehybridized for $3 \mathrm{~h}$ at $60^{\circ} \mathrm{C}$ in hybridization buffer containing $5 \times$ saline sodium citrate (SSC), $50 \%$ formamide, $1 \mathrm{mg} / \mathrm{ml}$ yeast tRNA, $0.1 \mathrm{mg} / \mathrm{ml}$ heparin, $0.1 \%$ Tween 20, $0.005 \mathrm{~m}$ EDTA, pH 8.0, and $0.1 \%$ CHAPS. Following prehybridization, the tissue was incubated in hybridization buffer containing Ube3a-ATS $3^{\prime}$ end probe. Posthybridization washes were performed sequentially at $60^{\circ} \mathrm{C}$ in prewarmed buffers:
$1 \times 15 \mathrm{~min}$ in $2 \times$ SSC, $3 \times 20 \mathrm{~min}$ in $0.2 \times$ SSC buffer. Tissue was further washed at room temperature $2 \times 10 \mathrm{~min}$ in $0.1 \mathrm{M}$ Tris- $\mathrm{HCl}, \mathrm{pH} 7.5,0.15 \mathrm{M}$ $\mathrm{NaCl}$. Tissue was then incubated in $3 \% \mathrm{H}_{2} \mathrm{O}_{2}$ in methanol and washed $3 \times 5 \mathrm{~min}$ in $0.1 \mathrm{M}$ Tris- $\mathrm{HCl}, \mathrm{pH} 7.5,0.15 \mathrm{M} \mathrm{NaCl}$ to eliminate endogenous hydrogen peroxidase activity. Sections were then incubated for $1 \mathrm{~h}$ in $1 \%$ blocking buffer (PerkinElmer), followed by incubation for $24 \mathrm{~h}$ at $4^{\circ} \mathrm{C}$ in anti-fluorescein-peroxidase (1:350; Roche) and primary antibodies to NeuN (1:650, EMD Millipore) or GFP (1:200, Aves Laboratory) in $1 \%$ blocking buffer with $10 \%$ normal goat serum. The following day, after washing $3 \times 10 \mathrm{~min}$ in TNT wash buffer $(0.1 \mathrm{~m}$ Tris-HCl, $\mathrm{pH} 7.5$, $0.15 \mathrm{M} \mathrm{NaCl}, 0.05 \%$ Tween 20 ), sections underwent a tyramide signal amplification with TSA plus 2,4-dinitrophenyl 1:50 in amplification diluent. Following a 7 min incubation, sections were washed with TNT wash buffer $3 \times 10 \mathrm{~min}$ and incubated in a 2,4-dinitrophenyl primary antibody conjugated with AlexaFluor-488 (1:500 dilution in TNT; Invitrogen), appropriate secondary antibodies to marker antibodies, and, as needed, IB4-Alexa-568 (1:100, Invitrogen) for $3 \mathrm{~h}$ at room temperature. Sections were washed in PBS, stained with DAPI, and coverslipped with Fluoro-Gel. All images were obtained using a Zeiss LSM 710 confocal microscope.

Immunohistochemistry. Adult male mice (P40-P75) were deeply anesthetized and perfused with 4\% PFA in $0.1 \mathrm{~m}$ phosphate buffer, $\mathrm{pH} 7.4$. Lumbar DRGs were removed and immersed in the same fixative for $5 \mathrm{~h}$ before cryoprotection for at least $48 \mathrm{~h}$ in $30 \%$ sucrose in phosphate buffer. Frozen ganglia were sectioned at $24 \mu \mathrm{m}$ and collected on SuperFrost Plus slides. The following primary antibodies were used in combinations for overnight incubations: mouse anti-UBE3A (1:300, Sigma, SAB1404508), chicken anti-GFP (1:800; Aves Laboratory, GFP-1020), rabbit anti-NF200 (1:750; Sigma, N4142), sheep anti-CGRP (1:250, Enzo Life Sciences, CA1137), and guinea pig anti-NeuN (1:250, EMD Millipore, ABN90P). Fluorescently tagged secondary antibodies were purchased from Invitrogen and Jackson ImmunoResearch Laboratories and used at 1:200. When appropriate, a fluorescent conjugate of Isolectin B4 (IB4; 1:100; Invitrogen) was added to secondary antibody incubations. All images were obtained using a Zeiss LSM 710 confocal microscope. Only neurons with clear UBE3A ${ }^{+}$nuclei were included in the cell counts.

Analysis of single-cell gene expression in DRG. Single-cell DRG gene expression data were analyzed by Usoskin et al. (2015), and cells previously classified as outliers were removed. $\log _{10}$-transformed expression values for each gene in the Ube3a locus (chr7:59,223,946-60,142,803 in the mm10 mouse reference genome) were averaged for each cell type and visualized in the Integrative Genomics Viewer (Robinson et al., 2011). The expression of Ube3a-ATS was estimated for each of the 622 single cells by averaging the $\log _{10}$ expression values for 18 of the genes in this locus whose expression was nonzero: Snurf, Ube3a, D7Ertd715e, Snrpn, Snord11612_loc10, Snord116_loc4, Snord116l1_loc1, Snord11611_loc3, A230073K19Rik, Snord116_loc8, Snord11611_loc9, Snord64, Snord11612_loc5, Snord116_loc3, Snord11612_loc4, Snord116_loc2, Ipw, and C230091D08Rik. These 18 genes serve as a proxy for Ube $3 a-A T S$ because current single-cell gene expression methodologies are not strand-specific and thus cannot discriminate between sense and antisense transcription. For the association test between Ube3a-ATS expression and Nefh expression, Nefh-high and Nefh-low groups were defined by $\log 10$ expression in single cells $>1.25$ or $<1.25$, respectively.

Behavioral testing. Ube $3 a$ knock-out mice were originally generated in the lab of A. Beaudet (Jiang et al., 1998). The Ube3a-floxed (Ube3 $a^{F L O X}$ ) mice were engineered at the University of North Carolina Animal Models Core (Berrios et al., 2016; Judson et al., 2016). The Ube $3 a^{F L O X / p+}$ female mice were crossed with Advillin-Cre ${ }^{-/-}$male mice (Hasegawa et al., 2007) to yield Ube3a ${ }^{\mathrm{FOXX} / \mathrm{p}^{+}}-$Advillin-Cre ${ }^{+/-}$and $\mathrm{Ube} 3 a^{+/+}-$Advillin-Cre ${ }^{+/-}$ mice. Mice were tested at 3-4 months of age. Mechanical sensitivity was measured using the up-down method with calibrated von Frey filaments. The cotton swab test uses the fluffed-out end of a cotton swab that was gently brushed across the hindpaw (Garrison et al., 2012). The frequency of responses to five brush strokes was calculated. Thermal withdrawal latency was measured using a Hargreaves apparatus (IITC) with a $20 \mathrm{~s}$ cutoff. For the tail immersion assay, each mouse was gently restrained in a towel, and the distal half of the tail was immersed into a water bath heated to $46.5^{\circ} \mathrm{C}$ or $49^{\circ} \mathrm{C}$. The latency to flick or withdraw the tail was 
measured once per mouse with a 40 and 30 s cutoff, respectively. In the hotplate assay, the mouse was placed onto a plate heated to $52^{\circ} \mathrm{C}$ and the latency to jump, shake, or lick the hindpaw was measured within the $30 \mathrm{~s}$ cutoff time. For the cold tail immersion assay, the distal half of the tail was immersed into $75 \%$ ethanol cooled to $-10^{\circ} \mathrm{C}$. The tail clip assay was performed as described previously (Lariviere et al., 2002). Cold withdrawal was performed by placing the mice on a Hargreaves apparatus (IITC) (Brenner et al., 2012). For the acetone test (Bautista et al., 2007), each mouse was placed into a Plexiglas chamber with a wire mesh floor. Acetone $(50 \mu \mathrm{l})$ was administered to the left hindpaw, and the time spent licking was measured for $1 \mathrm{~min}$. For the texture discrimination assay, mice were placed into a plastic rodent cage where one half was empty (plastic floor), whereas the other half floor was covered with water, gravel (All Purpose Gravel, Quikrete), smooth aquarium stones, sand (All Purpose Sand, Quikrete), or standard bedding (1/4 inch cob bedding, The Andersons). The mice were allowed to explore the chamber for $300 \mathrm{~s}$ ( $5 \mathrm{~min}$ ). The amount of time spent in the novel texture and the number of entries was recorded. For the rotarod assay, mice were placed on an accelerating rotarod. The speed was slowly increased from $3 \mathrm{rpm}$ to 30 rpm over a 5 min period. A trial was considered over when the mouse either fell off the rotarod or failed to remain on top. A 2 min break separated the first and second trials. The task was repeated $48 \mathrm{~h}$ later.

Experimental design and statistical analysis. Male mice were used for in situ and immunostaining. Male and female mice were used in all behavior experiments with the $n$ of each sex written in the figure legends. A two-tailed Student's $t$ test was used to test for statistical significance between WT and global/conditional Ube3a mutant mice using EXCEL 2016 (see Figs. 5, 6, 8, and 9).

Image analysis. Six sections of lumbar DRG per Ube $3 a^{m+/ p-Y F P}$ mouse $(n=3)$ were analyzed for coexpression of UBE3A-YFP and various markers. Only those neurons with obvious UBE3A-YFP ${ }^{+}$nuclei were evaluated for marker colocalization. At least 1,000 UBE3A-YFP ${ }^{+}$neurons were analyzed per mouse per marker combination. Values of percentage colocalization are expressed as the average number of neurons per section \pm SEM. Four lumbar sections were examined for the in situ using ImageJ. Images were embedded with a scale bar and used to convert pixels ${ }^{2}$ to $\mu \mathrm{m}^{2}$. Diameters were measured by drawing a line across each $\mathrm{NeuN}^{+}$neuron. Each image was thresholded to determine the weak and strong Ube3a-ATS-expressing $\mathrm{NeuN}^{+}$neurons.

\section{Results}

\section{Monoallelic expression of Ube3a in large-diameter, but not} small-diameter, DRG neurons

Previous studies examined Ube3a expression in various brain regions and the spinal cord (Huang et al., 2013; Judson et al., 2014), where the paternal copy of Ube3a is silenced by paternal Ube3a-ATS (Rougeulle et al., 1998; Yamasaki et al., 2003). To evaluate allelic expression of Ube3a in the DRG, we immunostained lumbar DRG sections from Ube $3 a^{m+/ p^{+}}$(wild-type [WT]) and Ube $3 a^{m-/ p^{+}}$(AS model) mice for UBE3A protein (Fig. 1). We found that UBE3A was present in all DRG neurons of $U b e 3 a^{m+/ p+}$ mice (Fig. $1 A, B$ ) and was generally present in smaller, but not larger, diameter neurons of $U b e 3 a^{m-1 p+}$ (AS) mice (Fig. 1C,D). Similar results were obtained using sacral DRG sections (data not shown). These data are consistent with monoallelic expression of maternal Ube3a in most largediameter, heavily myelinated, neurofilament-rich neurons, and with biallelic expression of Ube3a in small-diameter, unmyelinated, neurofilament-negative neurons.

\section{Paternal Ube3a colocalizes with nociceptive neuron markers}

To determine which small-diameter neurons express paternal $U b e 3 a$, we immunostained DRG sections from Ube $3 a^{m+/ p Y F P}$ mice, which express UBE3A-YFP from the paternal allele (Dindot et al., 2008), with antibodies to GFP and sensory neuron markers: IB4-binding, CGRP, and neurofilament-200 (NF200). IB4-binding marks small-diameter, unmyelinated, nonpeptidergic
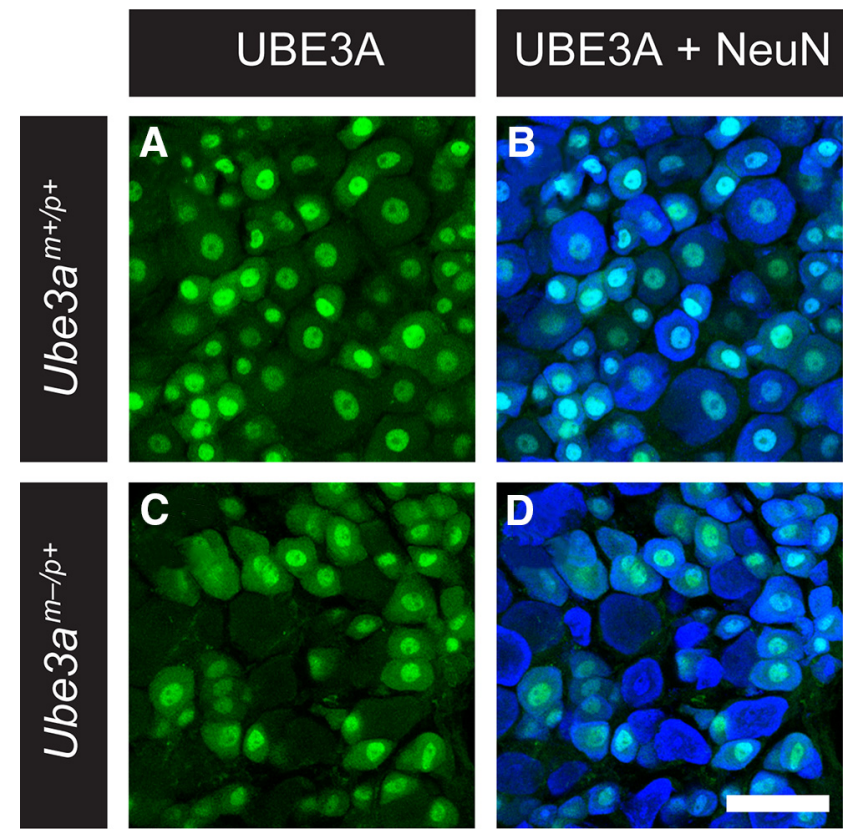

Figure 1. Expression of Ube3a in the DRG. Immunostaining of UBE3A and NeuN in lumbar DRG from $(\boldsymbol{A}, \boldsymbol{B})$ WT (Ube $\left.3 a^{m+/ p+}\right)$ and $(\boldsymbol{C}, \boldsymbol{D})$ AS $\left(U b e 3 a^{m-/ p+}\right)$ mice. Scale bar, $50 \mu \mathrm{m}$.

nociceptive neurons (Zylka et al., 2005; Cavanaugh et al., 2009). CGRP marks small-diameter, unmyelinated nociceptive neurons, and medium-diameter, thinly myelinated neurons (Lawson et al., 2002; McCoy et al., 2013). NF200 marks medium- and large-diameter myelinated neurons, including proprioceptors, mechanoreceptors, and nociceptors (Fundin et al., 1997). We found that paternal UBE3A-YFP was expressed in $76 \%$ of all IB4-binding neurons, $35 \%$ of all CGRP ${ }^{+}$neurons, and $22 \%$ of all NF200 ${ }^{+}$neurons (NF200; Fig. 2A-L; Table 1). Given that most large-diameter $\mathrm{NF} 200^{+}$neurons did not express paternal UBE3A-YFP but do contain UBE3A (Fig. 1), these data also support monoallelic, maternal Ube3a expression in large-diameter sensory neurons.

\section{Strong Ube3a-ATS expression in large-diameter DRG neurons} Ube3a-ATS blocks paternal Ube3a expression in cis-, so we hypothesized that Ube3a-ATS might be expressed at higher levels in large-diameter neurons. Indeed, using in situ hybridization, strong staining for Ube3a-ATS was detected in a greater percentage $(36.2 \%)$ of large-diameter neurons (soma diameter $>25 \mu \mathrm{m}$ ) than small-diameter neurons $(5.1 \%$, soma diameter $<25 \mu \mathrm{m})$ (Fig. 3A-C). Moreover, most (94.9\%) small-diameter neurons had weak to no Ube3a-ATS signal. We also examined colocalization of Ube3a-ATS and paternal UBE3A-YFP protein (Fig. 3D$F)$. We found that Ube3a-ATS was expressed at low levels in paternal UBE3A-YFP ${ }^{+}$neurons but was expressed at high levels in UBE3A-YFP ${ }^{-}$neurons (Fig. 3D,F). Collectively, our data indicate that neurons with the highest level of Ube3a-ATS monoallelically express $U b e 3 a$, whereas neurons with weak to no Ube $3 a-A T S$ biallelically express Ube3a. These data support a mechanism whereby Ube3a-ATS blocks full-length expression of paternal Ube3a in cis in large-diameter DRG neurons, similar to neurons in the CNS (Meng et al., 2013), but does not block paternal Ube3a expression in small-diameter neurons.

\section{Ube3a-ATS is expressed in neurofilament-rich sensory neurons}

Eleven molecularly distinct cell types were identified in the DRG using single-cell RNA sequencing (Usoskin et al., 2015). These 

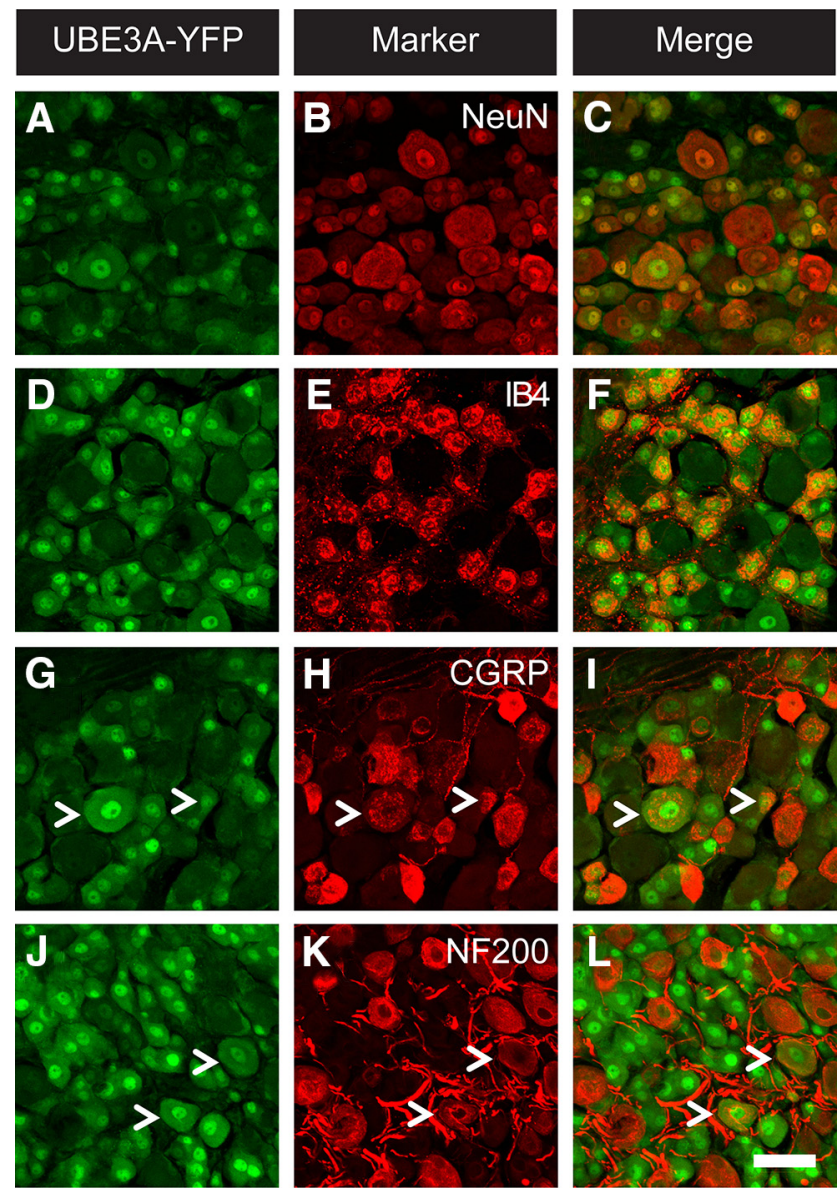

Figure 2. Expression of paternal UBE3A-YFP $\left(U b e 3 a^{m+/ p Y F P}\right)$ relative to DRG neuron markers. $A, D, G, J, U B E 3 A-Y F P$ detected with GFP antibody in DRG sections and colabeled with one of the following: $\boldsymbol{B}$, NeuN; $\boldsymbol{E}$, IB4; $\boldsymbol{H}$, CGRP; $\boldsymbol{K}$, NF200. $\boldsymbol{C}, \boldsymbol{F}, \boldsymbol{I}, \boldsymbol{L}$, Merged images. Scale bar, $50 \mu \mathrm{m}$.

Table 1. Percent colocalization of paternal UBE3A-YFP with nociceptive markers in DRG neurons

\begin{tabular}{lll}
\hline Marker & \% YFP $^{+}$that is Marker $^{+}$ & \% $^{+}$Marker $^{+}$that is YFP \\
\end{tabular}

cell types were classified into four broad subtypes based on neurofilament heavy chain (NF; Nefh), and markers of nonpeptidergic (NP), peptidergic (PEP), and tyrosine hydroxylasepositive (TH) neurons. We hypothesized that these data could be reanalyzed to ascertain which DRG cell types expressed Ube3aATS, and hence likely express Ube3a monoallelically. We estimated Ube3a-ATS levels from 18 genes in the Ube3a-ATS locus, including some isoforms of Snord116, which are contiguous with Ube3a-ATS based on knockdown studies (Meng et al., 2015), and additional paternally expressed genes in the immediate vicinity (such as Ipw and Snrpn; for complete list, see Materials and Methods). These Ube3a-ATS proxy genes were expressed at the highest level in neurofilament-rich cell types (NF1-5, PEP2) (Fig. 4). As previously noted (Usoskin et al., 2015), NF1-3 are low-threshold mechanoreceptors based on expression of Nefh, Calb1, Ntrk2 (TrkB), Ret, and Ntrk3 (TrkC), whereas NF4-5 are proprioceptors based on expression of Nefh, Ntrk $3^{\text {low }}$, and parvalbumin $(P V)$. PEP2 neurons expressed Ntrk1, Nefh, and Calca (encodes $\operatorname{CGRP} \alpha$ ), and these neurons are presumably thinly myelinated
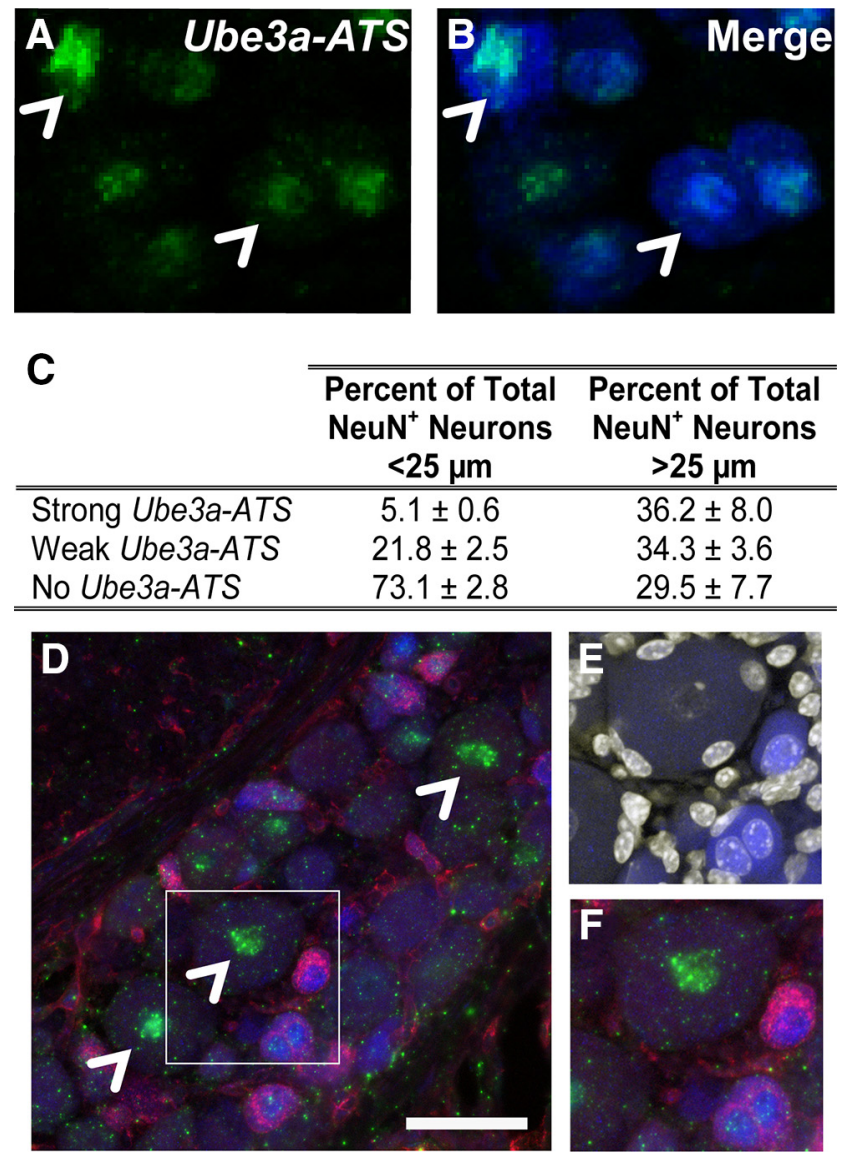

Figure 3. Ube3a-ATS is highly expressed in large-diameter DRG neurons. $\boldsymbol{A}$, In situ hybridization with an Ube3a-ATS probe in DRG. $\boldsymbol{B}$, Merged with NeuN image. $\boldsymbol{C}$, Table of each marker as a percentage of NeuN ${ }^{+}$neurons $>25$ and $<25 \mu \mathrm{m}$. D, In situ hybridization with Ube3a-ATS probe (green) and immunostained for IB4 (red) and UBE3A-YFP (blue). $\boldsymbol{E}$, Costaining for UBE3AYFP and DAPI, expanded from box in $\boldsymbol{D}$. $\boldsymbol{F}$, Merged image from box in $\boldsymbol{D}$. Scale bar: $\boldsymbol{D}, 50 \mu \mathrm{m}$.

A $\delta$ high-threshold mechanical nociceptors (Bai et al., 2015). In contrast, Ube3a-ATS proxy genes were expressed at low to undetectable levels in a majority of neurofilament-heavy-negative unmyelinated cell types (NP1-3, PEP1, and TH neurons). NP1-3 and PEP1 cell types are involved in pruritus and nociception, whereas TH neurons are low-threshold mechanoreceptors and sense pleasurable touch (Li et al., 2011).

Ube $3 a^{m-/ p+}$ mice show enhanced sensitivity to noxious heat and mechanical stimuli

Ube $3 a^{m-1 p^{+}}$(AS) mice have deficits in sociability, acquisition and reversal learning, motor function, and fear conditioning (Huang et al., 2013). However, somatosensation and nociception were not previously examined in AS mice. We thus tested WT and AS mice using innocuous and noxious mechanical stimuli (Fig. $5 A-C$ ) and noxious thermal stimuli (Fig. $5 D-F$ ). We found that WT and AS mice responded similarly to von Frey filaments applied to the hindpaw (Fig. 5A). In contrast, AS mice showed an enhanced response to tail clip, a noxious mechanical stimulus (Fig. 5B). WT and AS mice responded similarly to light touch (cotton swab assay; Fig. 5C).

We examined noxious thermal sensitivity by immersing the distal tail into water heated to $46.5^{\circ} \mathrm{C}$ or $49^{\circ} \mathrm{C}$ (Fig. $5 D, E$ ) and quantified the latency to flick. AS mice showed enhanced responses at both temperatures compared with WT mice (Fig. $5 D, E)$. However, no differences were found in the Hargreaves 

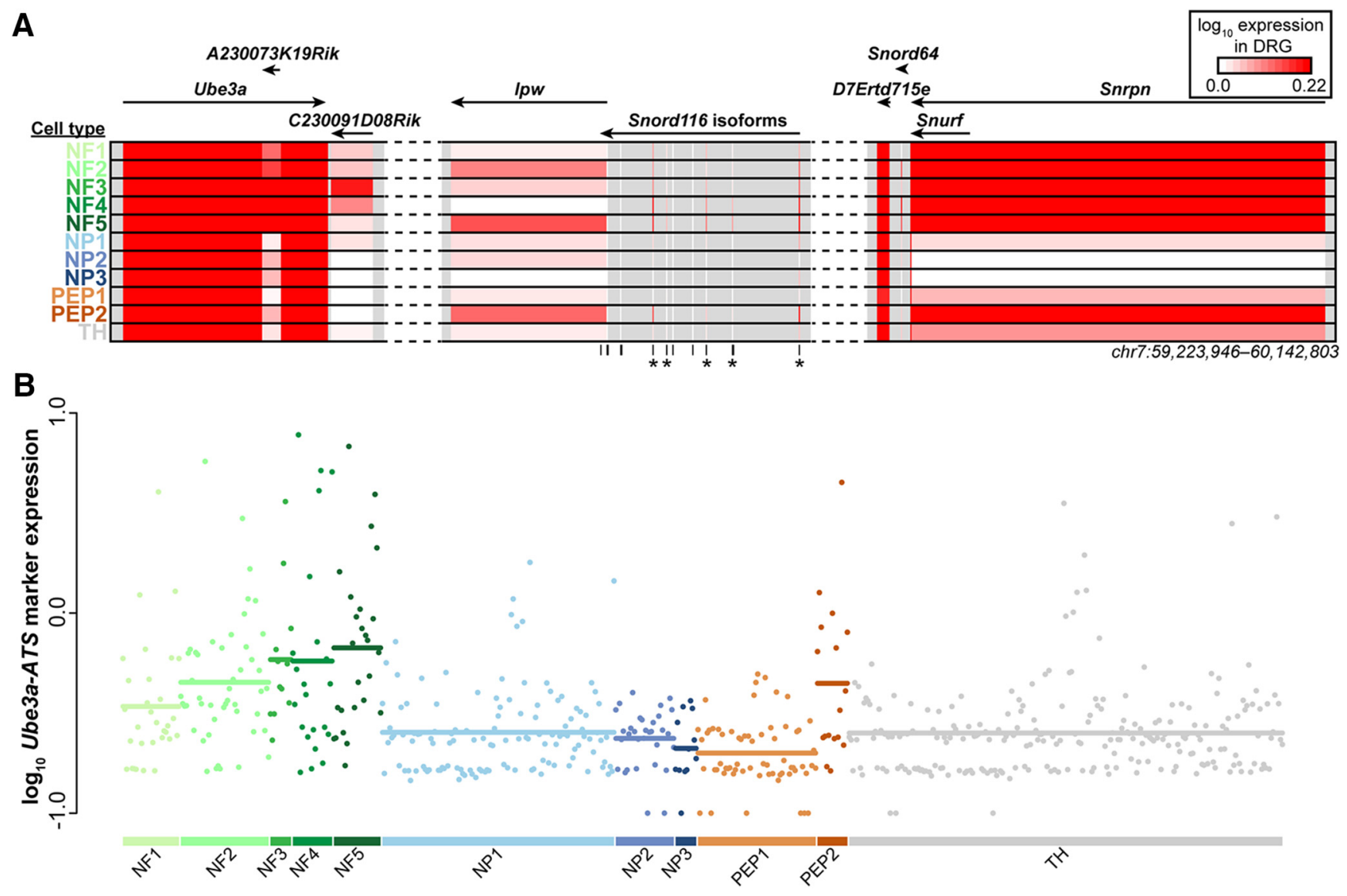

Figure 4. Single-cell analysis of Ube3a-ATS expression in DRG. $\boldsymbol{A}$, Expression of genes near Ube3a (chr7:59,223,946-60,142,803) in 11 DRG cell types, defined by single-cell transcriptomics (Usoskin et al., 2015). Expression values were $\log _{10}$-transformed and averaged across all single cells for each cell type. Arrows indicate direction of transcription. Longer intergenic regions (dashed lines) are not shown. *Isoforms of Snord 116 that are primarily expressed in neurofilament-heavy $\left(\mathrm{NF}^{+}\right.$) cell types, which include PEP2. B, Expression of Ube3a-ATS across all 622 single cells of the DRG using the average expression of 18 genes that serve as a proxy for Ube3a-ATS expression. Horizontal lines indicate the average expression across each of the single cells of a given cell type.

test (radiant heating of hindpaw; Fig. $5 F)$ or on a hotplate $\left(52^{\circ} \mathrm{C}\right.$; data not shown). Additionally, WT and AS mice responded similarly to cold stimuli, including the cold plantar assay (Brenner et al., 2012), tail immersion at $-10^{\circ} \mathrm{C}$, and acetone-evoked evaporative cooling of the hindpaw (data not shown). These data demonstrate that global maternal loss of Ube3a enhances nociception in AS mice when stimuli are applied to the tail.

\section{Ube $3 a^{m-/ p+}$ mice displayed heightened aversion to novel tactile environments}

Some individuals with AS show an unusual attraction to, or fascination with, water and crinkly items (Pelc et al., 2008). We thus gave WT and Ube $3 a^{m-/ p+}$ mice the opportunity to explore and discriminate novel tactile environments. Mice were placed in the empty half of a plastic cage, whereas the other half contained a thin layer of water, gravel, smooth stone, sand, or bedding (Fig. $6 A$, inset). Hydrophobic forces kept the water confined, so no physical barrier was needed. The amount of time spent on each side and the number of entries were measured over the $300 \mathrm{~s}$ test period (Fig. $6 A, B$ ). WT and Ube $3 a^{m-/ p+}$ mice spent considerably less time exploring the water side relative to the empty plastic side, suggesting that all mice show a strong aversion to water. $U b e 3 a^{m-1 p+}$ mice spent significantly less time in most of the novel tactile environments compared with WT mice (Fig. 6A) and entered most of the novel tactile environments significantly less often than WT mice (Fig. 6B). These data suggest that global loss of Ube3a heightens aversion to novel tactile environments.
Future studies will be required to tease out whether this phenotype is due to heightened somatosensory sensitivity, as we observed (Fig. 5), heightened anxiety (Pelc et al., 2008; Silva-Santos et al., 2015), and/or other factors.

\section{Conditional deletion of maternal Ube3a in the DRG does not impair nociception}

We next sought to determine whether the enhanced nociceptive phenotypes in AS mice were due to maternal loss of Ube3a in sensory neurons. To conditionally delete maternal Ube $3 a$ only in sensory ganglia, we crossed homozygous male Advillin-Cre mice with female Ube $3 a^{F L O X / p^{+}}$mice (Hasegawa et al., 2007; Minett et al., 2012; Berrios et al., 2016). Using immunohistochemistry, we confirmed that UBE3A was eliminated in large-diameter neurons of Ube $3 a^{F L O X / p^{+}}$mice, which express maternal Ube $3 a$, but was not eliminated in small-diameter neurons, which biallelically express Ube3a (Fig. 7A-D). However, no significant differences were observed between WT and conditional maternal Ube3a knock-out $\left(U b e 3 a^{F L O X / p^{+}}\right)$mice in thermal or mechanical sensitivity (Fig. $8 A-F$ ), with assays that probe cold sensitivity (cold tail immersion, cold plantar, and acetone-evoked evaporative cooling tests; data not shown), or in the spared nerve injury model of neuropathic pain (equal levels of allodynia were present on day 7 and 14 after injury; data not shown). These data suggest that the enhanced nociceptive phenotypes seen in AS mice are caused by loss of maternal Ube $3 a$ in the CNS, where expression is primarily 

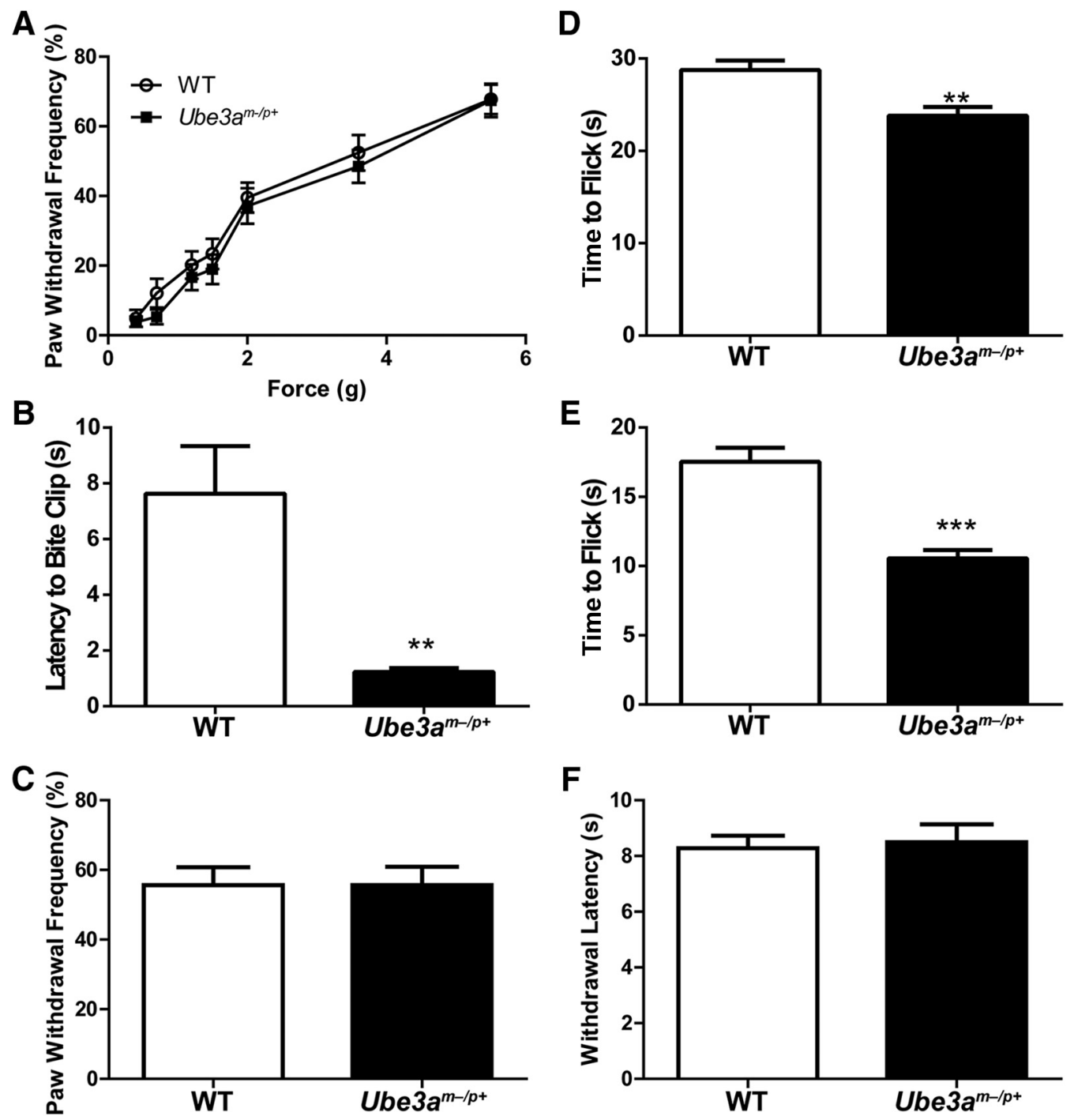

Figure 5. Ube $3 a^{m-/ p+}$ mice show enhanced responses to noxious mechanical and heat stimuli.Ube $3 a^{m-/ p+}$ mice were tested with mechanical stimuli. A, von Frey filaments of increasing force. $\boldsymbol{B}$, Tail dip ( $p=0.00054)$. C, Cotton swab. Mice were also tested with noxious heat stimuli. $\boldsymbol{D}$, Tail immersion $46.5^{\circ} \mathrm{C}(p=0.00053)$. $\boldsymbol{E}$, Tail immersion $49^{\circ} \mathrm{C}\left(p=6.30 \times 10^{-6}\right) . \boldsymbol{F}$, Radiant heating of hindpaw with Hargreaves apparatus. $t$ tests were used to compare responses between WT and Ube3 $a^{m-/ p+}$ mice. $n=10-12$ males and $2-4$ females/group, 12 weeks old. ${ }^{* *} p<0.005 ;{ }^{* * *} p<$ 0.0005 .
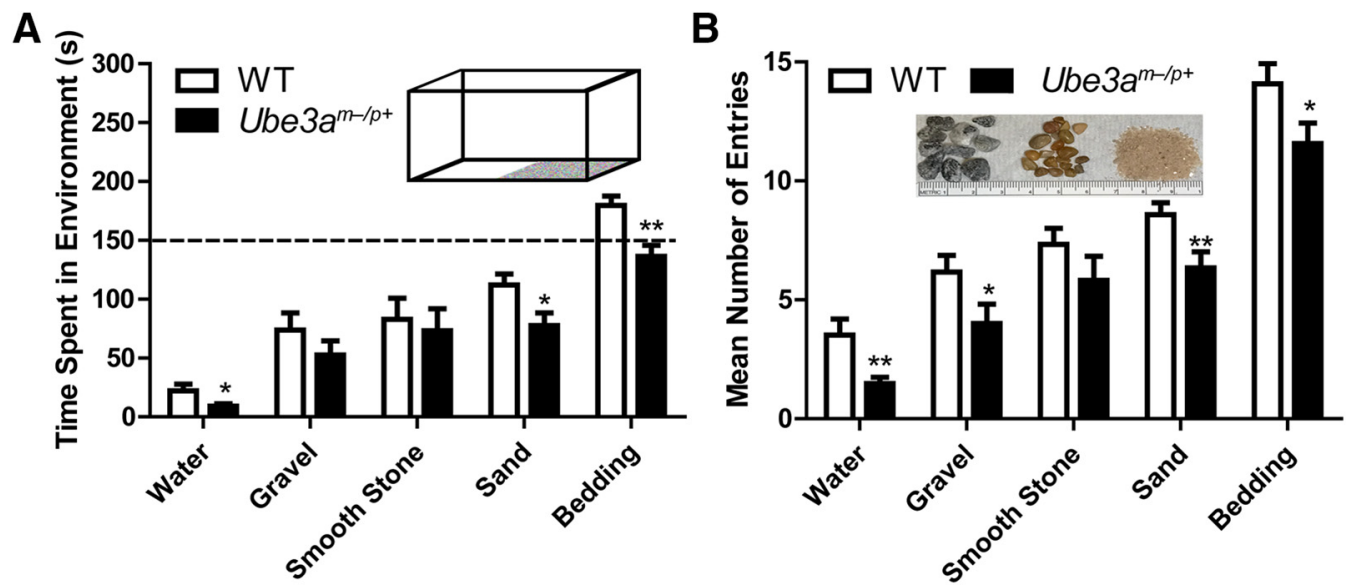

Figure 6. Ube $3 a^{m-1 p+}$ mice show heightened aversion to novel tactile environments. $A$, WT and Ube $3 a^{m-/ p+}$ mice were placed into the empty half of a rodent cage (inset). The other half contained a novel tactile environment (water, gravel, smooth stone, sand, or bedding). $A$, The amount of time spent exploring the novel environment (water, $p=0.014 ;$ sand, $p=0.0091 ;$ bedding, $p=0.00053$ ). $\boldsymbol{B}$, The mean number of entries into the novel environment was measured (water, $p=0.003$; gravel, $p=0.029 ;$ sand, $p=0.0048 ;$ bedding, $p=0.022$ ). $\boldsymbol{A}$, Dashed line indicates half of the total trial time. $\boldsymbol{B}$, Inset, Image of gravel, smooth stone, and sand used in texture assay. $t$ tests were used to compare responses between WT and Ube $3 a^{m-1 p+}$ mice. ${ }^{*} p<0.05$; ${ }^{* *} p<0.005$. 


\section{UBE3A}
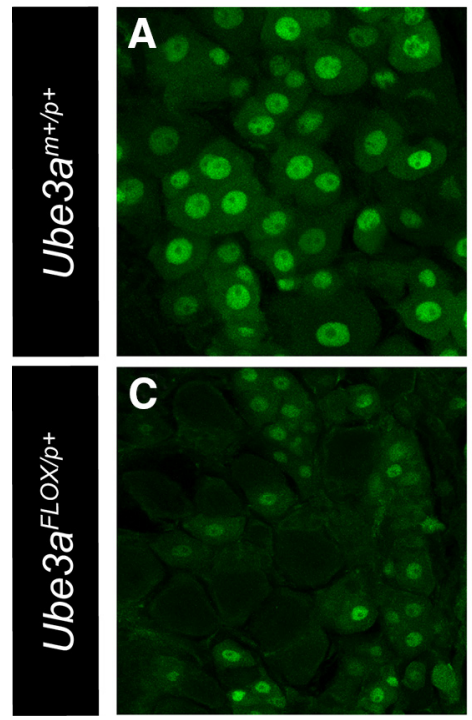

Figure 7. Conditional deletion of maternal Ube3a in mouse DRG with Advillin-Cre. Immunostaining of UBE3A and NeuN in lumbarDRG from $(\boldsymbol{A}, \boldsymbol{B})$ WT (Ube $3 a^{m+/ p+}$ Advillin-Cre ${ }^{+/-}$) and $(\boldsymbol{C}, \boldsymbol{D})$ Ube $3 a^{F L O X / p+}$ Advillin-Cre ${ }^{+/-}$mice. Scale bar: $\boldsymbol{D}, 50 \mu \mathrm{m}$. Confocal gain settings were equivalent to permit comparison of staining intensity between $\boldsymbol{A}, \boldsymbol{B}$ and $\boldsymbol{C}, \boldsymbol{D}$.

monoallelic, and not due to loss or haploinsufficiency of UBE3A in peripheral sensory neurons.

\section{Ube $3 a^{F L O X / p+}$ mice show no deficits in the rotarod assay or tactile discrimination}

The Ube $3 a^{m-1 p+}$ mice spent less time in novel tactile environments relative to WT mice (Fig. 6). To determine whether this phenotype was due to loss of Ube3a in the DRG, we tested $U b e 3 a^{F L O X / p^{+}}$mice in the tactile discrimination assay. We observed no significant differences between WT and Ube $3 a^{F L O X / p^{+}}$ mice in either the number of entries or the amount of time spent in novel tactile environments (Fig. $9 A, B$ ). WT and $U b e 3 a^{F L O X / p+}$ mice also showed no significant differences in a texture novel object recognition task (data not shown) (Orefice et al., 2016). These data suggest that the heightened aversion $U b e 3 a^{m-/ p+}$ mice displayed to novel tactile environments is centrally, not peripherally, mediated.

Previous studies examining $U b e 3 a^{m-1 p^{+}}$mice found deficits in the rotarod assay (Jiang et al., 1998; Huang et al., 2013), which could have a proprioceptive component. To determine whether conditional deletion of maternal Ube3a in sensory neurons affected rotarod performance, we tested WT and Ube $3 a^{F L O X / p+}$ mice using the rotarod assay (Fig. 9C). There was no change in the latency to fall off between the first and second trial, suggesting no motor or proprioceptive deficits in $U b e 3 a^{F L O X / p^{+}}$mice.

\section{Discussion}

Our study demonstrates that the mouse DRG contains a mixed population of Ube3a-expressing neurons; some express Ube $3 a$ monoallelically from the maternal allele, as in the brain, and others express Ube $3 a$ biallelically, as in non-neuronal and immature neuron cell types (Judson et al., 2014; Jones et al., 2016). Most large-diameter neurons express Ube $a$ monoallelically and contain high levels of Ube3a-ATS, suggesting that paternal Ube3a expression is restricted in large-diameter DRG neurons by transcriptional collision of sense and antisense RNA polymerases, as occurs in the CNS (Meng et al., 2013). A boundary element within Ube3a-ATS is hypothesized to control whether the Ube3aATS transcript terminates in the vicinity of Ipw and Snord116 genes, permitting paternal Ube3a expression in non-neuronal cells, or extends further $3^{\prime}$, blocking paternal Ube3a expression in mature neurons (Martins-Taylor et al., 2014). Genetic or pharmacological truncation of Ube3a-ATS can unsilence paternal Ube3a (Huang et al., 2011; Meng et al., 2013, 2015; Powell et al., 2013), strongly indicating that transcription of Ube3a-ATS blocks paternal Ube3a expression in cis. Future studies with small- and large-diameter DRG neurons could provide new insights into Ube3a-ATS transcript extension and the nature of the boundary element, and identify mechanisms that differentially regulate paternal Ube3a expression in different cell types. One might predict, for example, that molecular resection of the boundary element, or drugs that reduce Ube3a-ATS expression (Huang et al., 2011; Meng et al., 2015), will more noticeably elevate UBE3A levels in large- but not small-diameter neurons.

Small-diameter DRG neurons biallelically express Ube3a, contain markers of nociceptive neurons (IB4, CGRP), and lack NF200, whereas many larger-diameter DRG neurons monoallelically express $U b e 3 a$ and are neurofilament heavy chain-rich $\left(\mathrm{NF}_{200}{ }^{+}\right)$. Furthermore, neurofilament heavy chain (Nefh) expression was strongly associated with Ube3a-ATS expression at the single-cell level ( $p=2.003 \mathrm{e}-19$; $t$ test, Ube3a-ATS expression in Nefh-high vs Nefh-low DRG neurons), suggesting that Nefhhigh or Nelfh-low expression marks DRG neurons with monoallelic or biallelic Ube3a expression, respectively. Nefh is a marker of mature neurons (Carden et al., 1987), so this correlation could extend to other markers of neuronal maturity (Jones et al., 2016).

Additionally, we found that responses to noxious thermal and mechanical stimuli applied to the tail, but not hindpaw, were enhanced in AS mice. Despite monoallelic expression of Ube3a in many large-diameter DRG neurons, including $\mathrm{CGRP}^{+}$-myelinated high-threshold mechanoreceptors (PEP2 subset), these enhanced sensory responses were not likely due to loss of maternal Ube $3 a$ in peripheral sensory neurons, as these sensory phenotypes were not observed following DRG-selective deletion of maternal Ube3a. Although we cannot rule out possible effects on the functional properties of cutaneous afferents, our data suggest that enhanced nociceptive responses in AS mice are most likely due to maternal loss of Ube3a in mature neurons of the CNS, where Ube $3 a$ expression is maternal and monoallelic. Maternal loss of Ube $3 a$ has the potential to affect many brain regions where $U b e 3 a$ is monoallelically expressed and where pain signals are processed, including the somatosensory cortex, periaqueductal gray matter, amygdala, and hypothalamus (Jiang et al., 1998; Rougeulle et al., 1998; Landers et al., 2004; Lalande and Calciano, 2007; Dindot et al., 2008; Wallace et al., 2012). Disruption of synapse function and maturation, as occurs in AS mice, could alter sensory input and processing. Additionally, loss of Ube3a early in development could affect nociceptive signaling into adulthood (Fitzgerald, 2005). Future studies will be needed to resolve whether the nociceptive phenotypes observed here are due to global loss of maternal Ube3a throughout development, whether phenotypes are dependent on combined loss of maternal $U b e 3 a$ in both peripheral and central neurons, or whether phenotypes can be recapitulated following adult- and CNS-selective maternal Ube3a deletion.

We found that nociceptive responses were enhanced in the warm tail immersion $\left(46^{\circ} \mathrm{C}\right.$ and $\left.49.5^{\circ} \mathrm{C}\right)$ assay and the tail clip assay, but nociception was not enhanced when similar stimuli were applied to the hindpaw. The tail is innervated by sacral DRG 
A 2

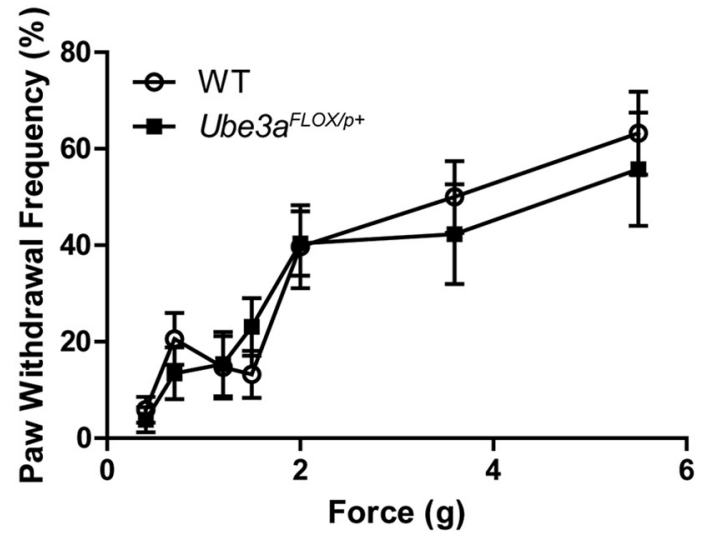

B

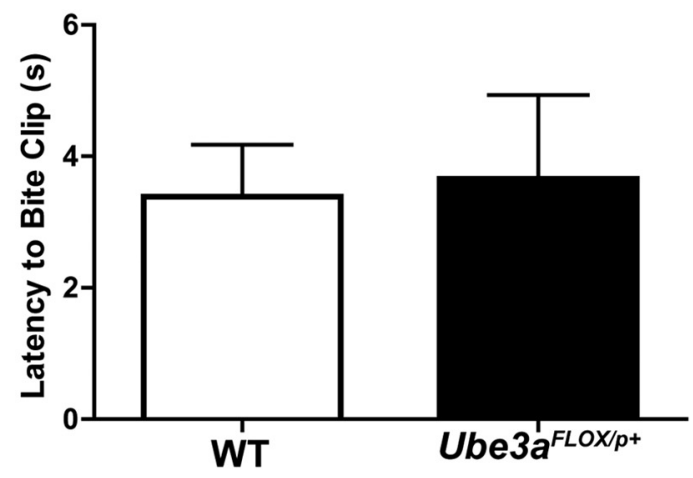

C

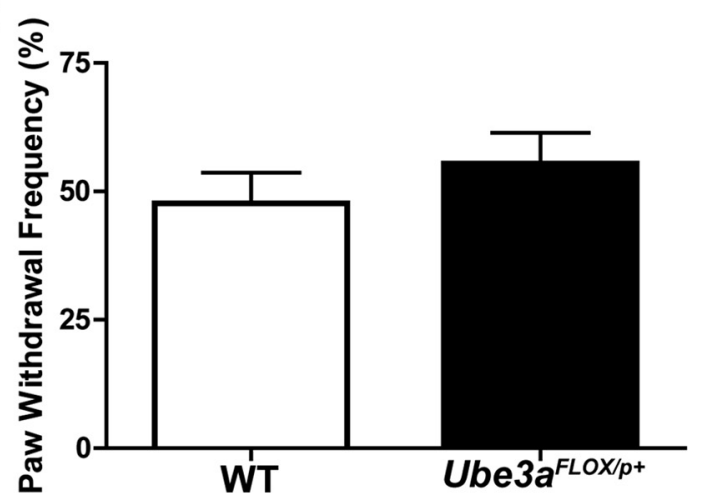

D

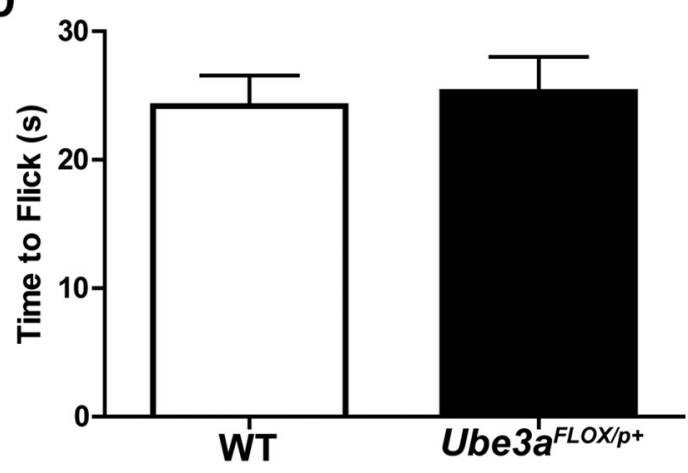

E

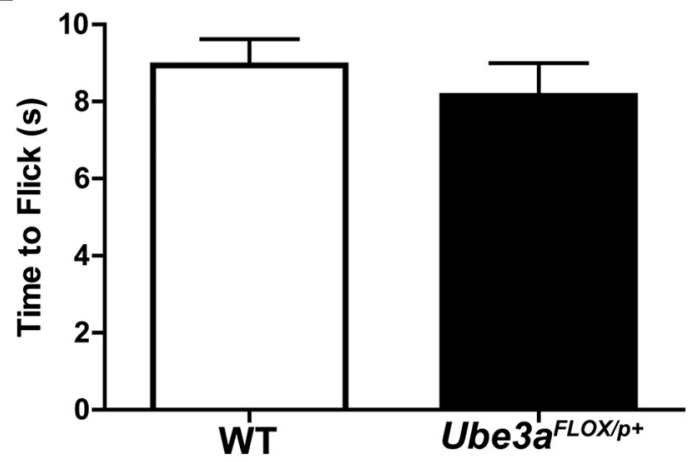

$\mathbf{F}$

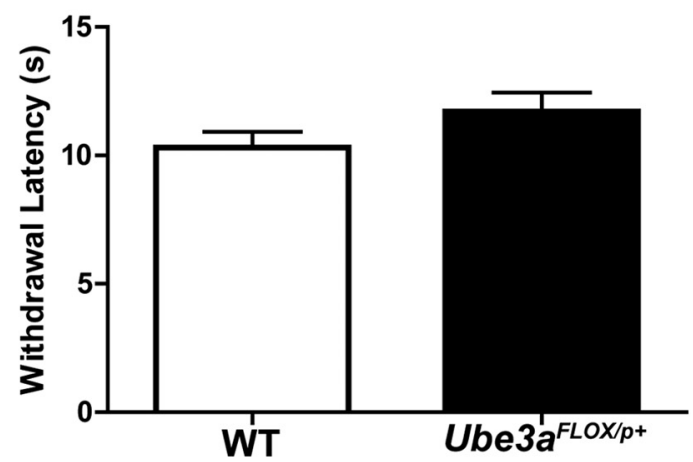

Figure 8. Conditional deletion of maternal Ube3a in somatosensory neurons does not alter nociceptive responses to mechanical or thermal stimuli. Ube3 $a^{F L O X / p+}$ mice were tested with mechanical stimuli. $\boldsymbol{A}$, von Frey filaments. $\boldsymbol{B}$, Tail clip. $\boldsymbol{C}$, Cotton swab. Mice were also tested with noxious heat stimuli. $\boldsymbol{D}$, Tail immersion $46.5^{\circ} \boldsymbol{C}$. $\boldsymbol{E}$, Tail immersion $49^{\circ} \boldsymbol{C}$. $\boldsymbol{F}$, Radiant heating of the hindpaw. $t$ tests were used to compare responses between WT and Ube $3 a^{F L O X / p+}$ mice. $n=10$ males and 4 females/group, 10-13 weeks old.
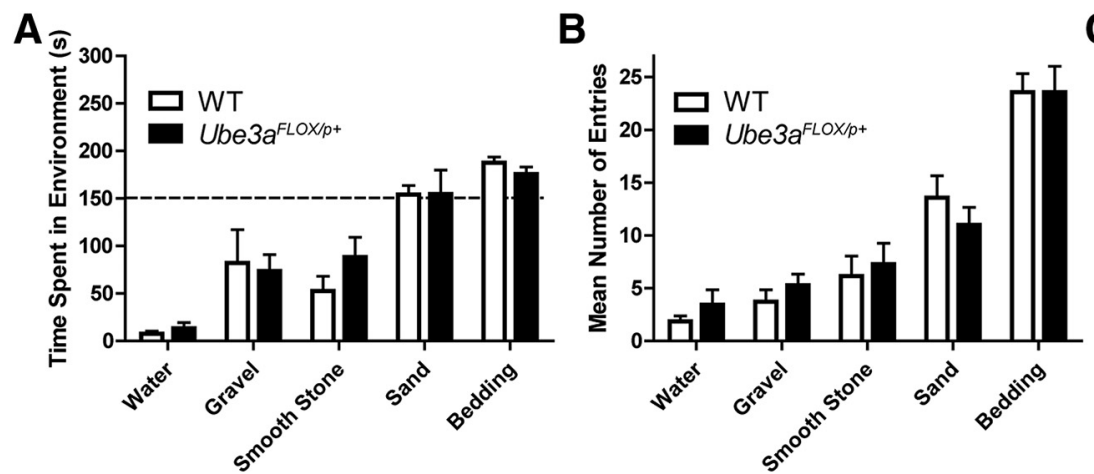

C

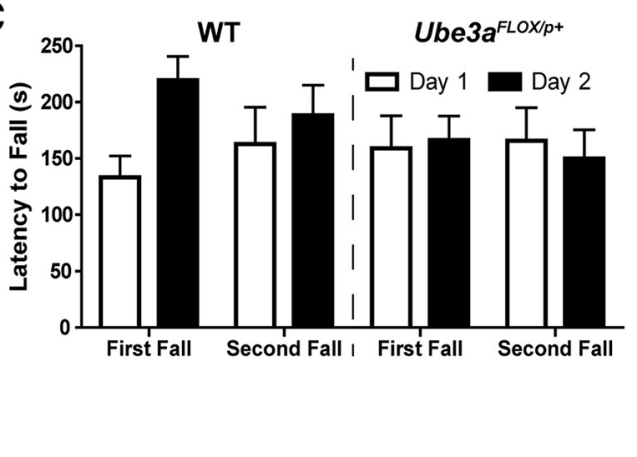

Figure 9. Conditional deletion of maternal Ube3a in somatosensory neurons does not impair tactile discrimination or rotarod performance. $\boldsymbol{A}$, The amount of time spent exploring the novel environment. $\boldsymbol{B}$, Mean number of entries into the novel environment. $\boldsymbol{A}$, Dashed line indicates half of the total trial time. $\boldsymbol{C}$, Latency to fall from an accelerating rotarod. A retest was performed $48 \mathrm{~h}$ after the first test. $n=3$ or 4 males and 3 or 4 females/group. $t$ tests were used to compare responses between WT and Ube $3 a^{F L X X / p+}$ mice. There were no significant differences between groups. 
neurons, whereas the hindpaw is innervated by lumbar DRG neurons. We found that Ube3a is biallelically expressed in smalldiameter neurons and maternally expressed in large-diameter neurons in lumbar and sacral DRG. Thus, a discrepancy in Ube $3 a$ expression between sacral and lumbar DRG is unlikely to contribute to phenotype discrepancies in tail- and hindpaw-focused assays. Other groups found that sensory phenotypes differ between the tail and hindpaw. For example, loss of Nav1.8 increased Randall-Selitto response threshold when applied to the tail but not to the hindpaw (Minett et al., 2014). Furthermore, tail and hindpaw thermal reflex responses are processed differently in the CNS. For example, central intracerebroventricular administration of morphine antagonizes the tail reflex response (Suh et al., 1989). Intrathecal administration of serotonergic and adrenergic receptor antagonists differentially interferes with this morphine response on tail reflex but not hotplate reflex responses (Suh et al., 1989). As another example, administration of muscimol, a GABA antagonist, into the midbrain reticular formation produced analgesia for the hotplate but not for the tail flick test (Baumeister and Frye, 1986). These data support the notion that tail- and hindpaw-reflexive responses are processed differently in the CNS. Global, but not sensory-neuron specific, loss of maternal Ube 3 a may thus differentially impact central circuits that process nociceptive information from the tail and the hindpaw.

One of the most reproducible phenotypes in AS mice is impaired balance and impaired locomotion on the rotarod (Huang et al., 2013). Of the DRG neuron subtypes, proprioceptors (NF4 and NF5) have the highest level of Ube3a-ATS expression, and hence likely express maternal but not paternal Ube3a. The neurobiological basis of motor deficits in AS individuals and AS mice has not been resolved but does not involve the cerebellum (Bruinsma et al., 2015). Although deficits in proprioception can affect balance and motor performance, Ube $3 a^{F L O X / p+}$ mice showed no deficit in the rotarod assay, suggesting motor phenotypes in AS mice are not due to loss of maternal Ube3a in proprioceptive neurons.

Our study, which makes use of reflexive responses to noxious and innocuous stimuli, indicates that global loss of maternal Ube $3 a$ enhances some forms of nociception in mice. This finding has implications for individuals with AS who, based on parent reports, show the opposite: a seemingly slow response to pain (Artigas-Pallarés et al., 2005; Walz and Baranek, 2006; Pelc et al., 2008). Given severe intellectual disability and lack of speech, individuals with AS may have difficulty interpreting pain signals and/or communicating their feelings appropriately to caregivers. Alternatively, the AS mouse model may not recapitulate somatosensory/pain phenotypes associated with AS. In light of our findings, a more rigorous and quantitative assessment of pain sensitivity in AS individuals is warranted. Future studies could include functional imaging of pain-related brain regions, to evaluate whether activation of these regions is impaired or whether activation is enhanced, as might be predicted from our study.

\section{References}

Adams D, Oliver C (2011) The expression and assessment of emotions and internal states in individuals with severe or profound intellectual disabilities. Clin Psychol Rev 31:293-306. CrossRef Medline

Artigas-Pallarés J, Brun-Gasca C, Gabau-Vila E, Guitart-Feliubadaló M, Camprubi-Sánchez C (2005) [Medical and behavioural aspects of Angelman syndrome]. Rev Neurol 41:649-656. Medline

Bai L, Lehnert BP, Liu J, Neubarth NL, Dickendesher TL, Nwe PH, Cassidy C, Woodbury CJ, Ginty DD (2015) Genetic identification of an expansive mechanoreceptor sensitive to skin stroking. Cell 163:1783-1795. CrossRef Medline
Baumeister AA, Frye GD (1986) Involvement of the midbrain reticular formation in self-injurious behavior, stereotyped behavior, and analgesia induced by intranigral microinjection of muscimol. Brain Res 369:231242. CrossRef Medline

Bautista DM, Siemens J, Glazer JM, Tsuruda PR, Basbaum AI, Stucky CL, Jordt SE, Julius D (2007) The menthol receptor TRPM8 is the principal detector of environmental cold. Nature 448:204-208. CrossRef Medline

Berrios J, Stamatakis AM, Kantak PA, McElligott ZA, Judson MC, Aita M, Rougie M, Stuber GD, Philpot BD (2016) Loss of UBE3A from THexpressing neurons suppresses GABA co-release and enhances VTA-NAc optical self-stimulation. Nat Commun 7:10702. CrossRef Medline

Brenner DS, Golden JP, Gereau RW 4th (2012) A novel behavioral assay for measuring cold sensation in mice. PLoS One 7:e39765. CrossRef Medline

Bruinsma CF, Schonewille M, Gao Z, Aronica EM, Judson MC, Philpot BD, Hoebeek FE, van Woerden GM, De Zeeuw CI, Elgersma Y (2015) Dissociation of locomotor and cerebellar deficits in a murine Angelman syndrome model. J Clin Invest 125:4305-4315. CrossRef Medline

Buiting K, Williams C, Horsthemke B (2016) Angelman syndrome: insights into a rare neurogenetic disorder. Nat Rev Neurol 12:584-593. CrossRef Medline

Carden MJ, Trojanowski JQ, Schlaepfer WW, Lee VM (1987) Two-stage expression of neurofilament polypeptides during rat neurogenesis with early establishment of adult phosphorylation patterns. J Neurosci 7:3489_ 3504. Medline

Cavanaugh DJ, Lee H, Lo L, Shields SD, Zylka MJ, Basbaum AI, Anderson DJ (2009) Distinct subsets of unmyelinated primary sensory fibers mediate behavioral responses to noxious thermal and mechanical stimuli. Proc Natl Acad Sci U S A 106:9075-9080. CrossRef Medline

DeLorey TM, Sahbaie P, Hashemi E, Li WW, Salehi A, Clark DJ (2011) Somatosensory and sensorimotor consequences associated with the heterozygous disruption of the autism candidate gene, Gabrb3. Behav Brain Res 216:36-45. CrossRef Medline

Dindot SV, Antalffy BA, Bhattacharjee MB, Beaudet AL (2008) The Angelman syndrome ubiquitin ligase localizes to the synapse and nucleus, and maternal deficiency results in abnormal dendritic spine morphology. Hum Mol Genet 17:111-118. CrossRef Medline

Ehlen JC, Jones KA, Pinckney L, Gray CL, Burette S, Weinberg RJ, Evans JA, Brager AJ, Zylka MJ, Paul KN, Philpot BD, DeBruyne JP (2015) Maternal Ube3a loss disrupts sleep homeostasis but leaves circadian rhythmicity largely intact. J Neurosci 35:13587-13598. CrossRef Medline

Fitzgerald M (2005) The development of nociceptive circuits. Nat Rev Neurosci 6:507-520. CrossRef Medline

Fundin BT, Silos-Santiago I, Ernfors P, Fagan AM, Aldskogius H, DeChiara TM, Phillips HS, Barbacid M, Yancopoulos GD, Rice FL (1997) Differential dependency of cutaneous mechanoreceptors on neurotrophins, trk receptors, and P75 LNGFR. Dev Biol 190:94-116. CrossRef Medline

Garrison SR, Dietrich A, Stucky CL (2012) TRPC1 contributes to lighttouch sensation and mechanical responses in low-threshold cutaneous sensory neurons. J Neurophysiol 107:913-922. CrossRef Medline

Greer PL, Hanayama R, Bloodgood BL, Mardinly AR, Lipton DM, Flavell SW, Kim TK, Griffith EC, Waldon Z, Maehr R, Ploegh HL, Chowdhury S, Worley PF, Steen J, Greenberg ME (2010) The Angelman Syndrome protein Ube3A regulates synapse development by ubiquitinating arc. Cell 140:704-716. CrossRef Medline

Hasegawa H, Abbott S, Han BX, Qi Y, Wang F (2007) Analyzing somatosensory axon projections with the sensory neuron-specific Advillin gene. J Neurosci 27:14404-14414. CrossRef Medline

Huang HS, Allen JA, Mabb AM, King IF, Miriyala J, Taylor-Blake B, Sciaky N, Dutton JW Jr, Lee HM, Chen X, Jin J, Bridges AS, Zylka MJ, Roth BL, Philpot BD (2011) Topoisomerase inhibitors unsilence the dormant allele of Ube3a in neurons. Nature 481:185-189. CrossRef Medline

Huang HS, Burns AJ, Nonneman RJ, Baker LK, Riddick NV, Nikolova VD, Riday TT, Yashiro K, Philpot BD, Moy SS (2013) Behavioral deficits in an Angelman syndrome model: effects of genetic background and age. Behav Brain Res 243:79-90. CrossRef Medline

Jiang YH, Armstrong D, Albrecht U, Atkins CM, Noebels JL, Eichele G, Sweatt JD, Beaudet AL (1998) Mutation of the Angelman ubiquitin ligase in mice causes increased cytoplasmic p53 and deficits of contextual learning and long-term potentiation. Neuron 21:799-811. CrossRef Medline

Jiang YH, Pan Y, Zhu L, Landa L, Yoo J, Spencer C, Lorenzo I, Brilliant M, Noebels J, Beaudet AL (2010) Altered ultrasonic vocalization and impaired learning and memory in Angelman syndrome mouse model with a 
large maternal deletion from Ube3a to Gabrb3. PLoS One 5:e12278. CrossRef Medline

Jones KA, Han JE, DeBruyne JP, Philpot BD (2016) Persistent neuronal Ube3a expression in the suprachiasmatic nucleus of Angelman syndrome model mice. Sci Rep 6:28238. CrossRef Medline

Judson MC, Sosa-Pagan JO, Del Cid WA, Han JE, Philpot BD (2014) Allelic specificity of Ube3a expression in the mouse brain during postnatal development. J Comp Neurol 522:1874-1896. CrossRef Medline

Judson MC, Wallace ML, Sidorov MS, Burette AC, Gu B, van Woerden GM, King IF, Han JE, Zylka MJ, Elgersma Y, Weinberg RJ, Philpot BD (2016) GABAergic neuron-specific loss of Ube3a causes Angelman syndromelike EEG abnormalities and enhances seizure susceptibility. Neuron 90: 56-69. CrossRef Medline

Kishino T, Lalande M, Wagstaff J (1997) UBE3A/E6-AP mutations cause Angelman syndrome. Nat Genet 15:70-73. CrossRef Medline

Lalande M, Calciano MA (2007) Molecular epigenetics of Angelman syndrome. Cell Mol Life Sci 64:947-960. CrossRef Medline

Landers M, Bancescu DL, Le Meur E, Rougeulle C, Glatt-Deeley H, Brannan C, Muscatelli F, Lalande M (2004) Regulation of the large $(\sim 1000 \mathrm{~kb})$ imprinted murine Ube3a antisense transcript by alternative exons upstream of Snurf/Snrpn. Nucleic Acids Res 32:3480-3492. CrossRef Medline

Lariviere WR, Wilson SG, Laughlin TM, Kokayeff A, West EE, Adhikari SM, Wan Y, Mogil JS (2002) Heritability of nociception: III. Genetic relationships among commonly used assays of nociception and hypersensitivity. Pain 97:75-86. CrossRef Medline

LaSalle JM, Reiter LT, Chamberlain SJ (2015) Epigenetic regulation of UBE3A and roles in human neurodevelopmental disorders. Epigenomics 7:1213-1228. CrossRef Medline

Lawson SN, Crepps B, Perl ER (2002) Calcitonin gene-related peptide immunoreactivity and afferent receptive properties of dorsal root ganglion neurones in guinea-pigs. J Physiol 540:989-1002. CrossRef Medline

Li L, Rutlin M, Abraira VE, Cassidy C, Kus L, Gong S, Jankowski MP, Luo W, Heintz N, Koerber HR, Woodbury CJ, Ginty DD (2011) The functional organization of cutaneous low-threshold mechanosensory neurons. Cell 147:1615-1627. CrossRef Medline

Mabb AM, Judson MC, Zylka MJ, Philpot BD (2011) Angelman syndrome: insights into genomic imprinting and neurodevelopmental phenotypes. Trends Neurosci 34:293-303. CrossRef Medline

Martins-Taylor K, Hsiao JS, Chen PF, Glatt-Deeley H, De Smith AJ, Blakemore AI, Lalande M, Chamberlain SJ (2014) Imprinted expression of UBE3A in non-neuronal cells from a Prader-Willi syndrome patient with an atypical deletion. Hum Mol Genet 23:2364-2373. CrossRef Medline

Matsuura T, Sutcliffe JS, Fang P, Galjaard RJ, Jiang YH, Benton CS, Rommens JM, Beaudet AL (1997) De novo truncating mutations in E6-AP ubiquitin-protein ligase gene (UBE3A) in Angelman syndrome. Nat Genet 15:74-77. CrossRef Medline

McCoy ES, Taylor-Blake B, Street SE, Pribisko AL, Zheng J, Zylka MJ (2013) Peptidergic CGRPalpha primary sensory neurons encode heat and itch and tonically suppress sensitivity to cold. Neuron 78:138-151. CrossRef Medline

Meng L, Person RE, Huang W, Zhu PJ, Costa-Mattioli M, Beaudet AL (2013) Truncation of Ube3a-ATS unsilences paternal Ube3a and ameliorates behavioral defects in the Angelman syndrome mouse model. PLoS Genet 9:e1004039. CrossRef Medline

Meng L, Ward AJ, Chun S, Bennett CF, Beaudet AL, Rigo F (2015) Towards a therapy for Angelman syndrome by targeting a long non-coding RNA. Nature 518:409-412. CrossRef Medline

Minett MS, Nassar MA, Clark AK, Passmore G, Dickenson AH, Wang F, Malcangio M, Wood JN (2012) Distinct Nav1.7-dependent pain sensations require different sets of sensory and sympathetic neurons. Nat Commun 3:791. CrossRef Medline

Minett MS, Eijkelkamp N, Wood JN (2014) Significant determinants of mouse pain behaviour. PLoS One 9:e104458. CrossRef Medline

Numata K, Kohama C, Abe K, Kiyosawa H (2011) Highly parallel SNP genotyping reveals high-resolution landscape of mono-allelic Ube3a ex- pression associated with locus-wide antisense transcription. Nucleic Acids Res 39:2649-2657. CrossRef Medline

Orefice LL, Zimmerman AL, Chirila AM, Sleboda SJ, Head JP, Ginty DD (2016) Peripheral mechanosensory neuron dysfunction underlies tactile and behavioral deficits in mouse models of ASDs. Cell 166:299-313. CrossRef Medline

Pelc K, Cheron G, Dan B (2008) Behavior and neuropsychiatric manifestations in Angelman syndrome. Neuropsychiatr Dis Treat 4:577-584. Medline

Powell WT, Coulson RL, Gonzales ML, Crary FK, Wong SS, Adams S, Ach RA, Tsang P, Yamada NA, Yasui DH, Chédin F, LaSalle JM (2013) R-loop formation at Snord116 mediates topotecan inhibition of Ube3aantisense and allele-specific chromatin decondensation. Proc Natl Acad Sci U S A 110:13938-13943. CrossRef Medline

Robinson JT, Thorvaldsdóttir H, Winckler W, Guttman M, Lander ES, Getz G, Mesirov JP (2011) Integrative genomics viewer. Nat Biotechnol 29: 24-26. CrossRef Medline

Rougeulle C, Glatt H, Lalande M (1997) The Angelman syndrome candidate gene, UBE3A/E6-AP, is imprinted in brain. Nat Genet 17:14-15. CrossRef Medline

Rougeulle C, Cardoso C, Fontés M, Colleaux L, Lalande M (1998) An imprinted antisense RNA overlaps UBE3A and a second maternally expressed transcript. Nat Genet 19:15-16. CrossRef Medline

Saitoh S, Harada N, Jinno Y, Hashimoto K, Imaizumi K, Kuroki Y, Fukushima Y, Sugimoto T, Renedo M, Wagstaff J (1994) Molecular and clinical study of 61 Angelman syndrome patients. Am J Med Genet 52: 158-163. CrossRef Medline

Silva-Santos S, van Woerden GM, Bruinsma CF, Mientjes E, Jolfaei MA, Distel B, Kushner SA, Elgersma Y (2015) Ube3a reinstatement identifies distinct developmental windows in a murine Angelman syndrome model. J Clin Invest 125:2069-2076. CrossRef Medline

Sinnett D, Wagstaff J, Glatt K, Woolf E, Kirkness EJ, Lalande M (1993) High-resolution mapping of the gamma-aminobutyric acid receptor subunit beta 3 and alpha 5 gene cluster on chromosome 15q11-q13, and localization of breakpoints in two Angelman syndrome patients. Am J Hum Genet 52:1216-1229. Medline

Suh HH, Fujimoto JM, Tseng LL (1989) Differential mechanisms mediating beta-endorphin- and morphine-induced analgesia in mice. Eur J Pharmacol 168:61-70. CrossRef Medline

Sutcliffe JS, Jiang YH, Galijaard RJ, Matsuura T, Fang P, Kubota T, Christian SL, Bressler J, Cattanach B, Ledbetter DH, Beaudet AL (1997) The E6-Ap ubiquitin-protein ligase (UBE3A) gene is localized within a narrowed Angelman syndrome critical region. Genome Res 7:368-377. CrossRef Medline

Ugarte SD, Homanics GE, Firestone LL, Hammond DL (2000) Sensory thresholds and the antinociceptive effects of GABA receptor agonists in mice lacking the beta3 subunit of the GABA(A) receptor. Neuroscience 95:795-806. CrossRef Medline

Usoskin D, Furlan A, Islam S, Abdo H, Lönnerberg P, Lou D, Hjerling-Leffler J, Haeggström J, Kharchenko O, Kharchenko PV, Linnarsson S, Ernfors P (2015) Unbiased classification of sensory neuron types by large-scale single-cell RNA sequencing. Nat Neurosci 18:145-153. CrossRef Medline

Wallace ML, Burette AC, Weinberg RJ, Philpot BD (2012) Maternal loss of Ube3a produces an excitatory/inhibitory imbalance through neuron type-specific synaptic defects. Neuron 74:793-800. CrossRef Medline

Walz NC, Baranek GT (2006) Sensory processing patterns in persons with Angelman syndrome. Am J Occup Ther 60:472-479. CrossRef Medline

Williams CA, Beaudet AL, Clayton-Smith J, Knoll JH, Kyllerman M, Laan LA, Magenis RE, Moncla A, Schinzel AA, Summers JA, Wagstaff J (2006) Angelman syndrome 2005: updated consensus for diagnostic criteria. Am J Med Genet A 140:413-418. CrossRef Medline

Yamasaki K, Joh K, Ohta T, Masuzaki H, Ishimaru T, Mukai T, Niikawa N, Ogawa M, Wagstaff J, Kishino T (2003) Neurons but not glial cells show reciprocal imprinting of sense and antisense transcripts of Ube3a. Hum Mol Genet 12:837-847. CrossRef Medline

Zylka MJ, Rice FL, Anderson DJ (2005) Topographically distinct epidermal nociceptive circuits revealed by axonal tracers targeted to Mrgprd. Neuron 45:17-25. CrossRef Medline 